\title{
Effect of Sub-Surface Drainage System on Soil Chemical Properties and Yield of Rice Crop at Head Region of Tungabhadra Command Area
}

\author{
K. Mallika ${ }^{1 *}$, M.S. Ayyanagowdar ${ }^{1}$, B.S. Polisgowdar ${ }^{1}$, U. Satish Kumar ${ }^{1}$, \\ M.V. Ravi ${ }^{2}$ and Nagaraj ${ }^{3}$
}

${ }^{1}$ Department of Soil and Water Engineering, College of Agricultural Engineering, University of Agricultural Sciences, Raichur-584104, Karnataka, India

${ }^{2}$ Department of Soil Science and Agricultural Chemistry, University of Agricultural Sciences, Raichur-584104, Karnataka, India

${ }^{3}$ Department of Mathematics, University of Agricultural Sciences, Raichur-584104, Karnataka, India

*Corresponding author

\section{A B S T R A C T}

Keywords

Vital role, Agriculture,

Economic

Article Info

Accepted:

10 September 2018 Available Online:

10 October 2018
Studies on subsurface drainage were carried out on silty clay and clay soils in Gundur village from 2015 to 2016 . The mean $\mathrm{pH}$ of samples ranged from 8.16 to 8.35 before sowing and 8.21 to 8.41 after harvesting and before sowing the electrical conductivity ranged from 10.92 to $14.65 \mathrm{dS} \mathrm{m}^{-1}$ and 9.28 to $13.68 \mathrm{dS} \mathrm{m}^{-1}$ after harvesting. Similarly, the $\mathrm{Ca}^{2+}+\mathrm{Mg}^{2+}$ and $\mathrm{Na}^{+}$values were in the range of 34.01 to 37.14 and 10.47 to 12.89 Meq/100g before sowing of crops, after harvesting of the crops results obtained were in range of 33.34 to $36.92,10.92$ to $12.16 \mathrm{Meq} / 100 \mathrm{~g}$ of soil. The ESP values were in the range of 15.11 to 17.74 before sowing and 13.86 to 16.69 after harvesting of crop. A glance at results reveals that $\mathrm{pH}$ was observed to be increased due to sodic nature of soil and excess application of the fertilizer. ESP was noticed to be reduced in smaller amount as compared to pre-sowing conditions, gypsum needed to be applied in required amount in order to turn the soil from sodicity to non-sodic soils. Finally, the yield was observed to be increased as $52.50 \mathrm{q} \mathrm{ha}^{-1}$ as compared to pre drainage conditions of $38.50 \mathrm{q} \mathrm{ha}^{-1}$.

\section{Introduction}

Agriculture plays a vital role in the Indian economy with its large resources of land, water and sunshine. Despite the focus on industrialisation, agriculture remains a dominant sector of the Indian economy both in terms of contribution to gross product as well as a source of employment to millions across the country. The Indian agriculture sector accounted for 13.7 per cent of India's gross domestic product and employed just a little less than 60 per cent of the country's workforce in 2013. The statement "Agriculture Sustains Life, but Irrigation Sustains Agriculture" is true for India. The spectacular development of irrigation since independence in India is unparalleled in the world; which has greatly boosted the agricultural production. Irrigation 
development in India, with a mere 22.7 M ha during 1950 has gone up to $114.8 \mathrm{M}$ ha at present. However, the same attention has not been given to land drainage to create conductive atmosphere to the crop growth. As a result, the impact of irrigation over decades due to the absence of appropriate drainage measures and unscientific land and water management practices over the years have led to groundwater table rise to nearby or at root zone. The water table rise also brings up salts with it from subsurface thereby rendering salinity in the root zone. According to the FAO Land and Plant Nutrition Management Service, a significant proportion of cultivated land is salt-affected globally. Of the current $230 \mathrm{M}$ ha of irrigated land, $45 \mathrm{M}$ ha are waterlogged and salt-affected, 19.5 per cent and of the 1,500 $\mathrm{M}$ ha under dry land agriculture, $32 \mathrm{M}$ ha are salt-affected. It is estimated that up to 20 per cent of irrigated land in the world is affected by different levels of salinity and sodium content (Fard et al., 2007). In India about $12 \mathrm{M}$ ha of land area is affected by water logging and soil salinity from Kashmir to Kanya kumari and from east to west. If the natural drainage is insufficient to remove excess water and salts away from an affected area, the subsurface drainage technology has been used for reclamation of water logged and salt affected lands in many parts of the country, the system mainly consists of corrugated perforated PVC drain pipes and synthetic materials as drain envelope. The areas with drainage system soil conditions improved significantly and yield of paddy, sugarcane, betel vine and turmeric increased by $30,19,30$ and 11 percent, respectively as compared to the yield obtained from the fields that were not drained (Srinivasulu et al., 2006). The study area selected for the study comes under the command area of LBMC. The study area is located at Gundur village in Gangavati taluk of Koppal district at the head region with an area of 149.25 ha (G-IIIA and G-IVA blocks) was affected by the problems of water logging and salinity leading to under productivity of crops. In order to tackle the problems of Water logging and salinity the subsurface drainage system was installed.

\section{Materials and Methods}

\section{Study area and climate}

The area selected for the present study comes under the command of Tungabhadra Left Bank Canal (TLBC) of TBP and is located in the Gundur village of Koppal district, Karnataka. The annual average rainfall of the nearest rain gauge station at Siddapur village is $582 \mathrm{~mm}$. The soils present in the study area are predominantly vertisols shallow to medium black soils and the texture of top soil is silty clay, while the lower soils are clay. The clay content of the soil generally ranged from 47 to 52 per cent.

\section{Observations recorded}

In order to carry out systematic studies, the sampling points were identified using GPS. The soil samples were collected at different depths of 0-30, 30-60, 60-90 and 90-120 cm in different points before sowing and after harvesting. The chemical analysis included estimating $\mathrm{pH}, \mathrm{EC}, \mathrm{Na}^{+}, \mathrm{Ca}^{2+}+\mathrm{Mg}^{2+}$, ESP by adopting standard procedures to know the salinity and sodium level etc.

\section{Results and Discussion}

\section{Effect of sub-surface drainage on soil properties}

\section{Soil reaction}

The data presented in Table 1 reveals that the mean $\mathrm{pH}$ values ranged from 8.25 to 8.686 before sowing. Similarly, the mean $\mathrm{pH}$ values after the harvesting varied from 8.28 to 8.68 . 
The mean $\mathrm{pH}$ value before sowing and after harvesting was observed to be increasing as the depth increases. The standard error values for different depths at 0-30, 30-60, 60-90 and $90-120 \mathrm{~cm}$ were found to be $0.06,0.05,0.04$ and 0.06 respectively, which indicated that there was no much difference in $\mathrm{pH}$ values drawn from same depths at different points.

From $60-120 \mathrm{~cm}$ depth, the $\mathrm{pH}$ shows sodic nature of soil, in such cases gypsum should be applied as amendment particularly to sodic soils, which would have reduced the sodicity of the soils considerably. Therefore, gypsum needs to be applied to the sodic portion of the affected area to quicken the process for complete reclamation of land. These observations were in line with the past studies, which revealed that the $\mathrm{pH}$ of the soil after the implementation of the subsurface drainage system increased (Barker, 2000; Mathew et al., 2001; Babu et al., 2008).

\section{Electrical conductivity (ECe)}

The soil samples were taken from 0-30, 30-60, 60-90 and 90-120 $\mathrm{cm}$ depths at various points before transplantation and after harvesting during kharif 2015-'16 (or before transplantation in rabi 2016) and analysed for soil salinity $\left(\mathrm{EC}_{\mathrm{e}}\right)$. The mean, standard error, minimum and maximum soil salinity values before transplantation and after harvest crop are presented in Table 2. The minimum and maximum soil salinity values of before transplantation kharif 2015 were 10.67 and $15.78 \mathrm{dS} \mathrm{m}^{-1}$ at $0-30 \mathrm{~cm}$ depth, 9.36 and 14.33 $\mathrm{dS} \mathrm{m} \mathrm{m}^{-1}$ at $30-60 \mathrm{~cm}$ depth, 7.45 and $13.27 \mathrm{dS}$ $\mathrm{m}^{-1}$ at $60-90 \mathrm{~cm}$ depth and 8.22 and $12.68 \mathrm{dS}$ $\mathrm{m}^{-1}$ at $90-120 \mathrm{~cm}$ depth respectively. The mean soil salinity values ranged from 9.03 to $13.19 \mathrm{dS} \mathrm{m} \mathrm{m}^{-1}$ at different depths before transplantation during kharif 2015 (Table 2 and Fig. 1). The standard error values of soil salinity before transplantation were $0.12,0.16$, 0.17 and 0.18 at $0-30,30-60,60-90$ and 90 -
$120 \mathrm{~cm}$ depths respectively, which indicated that, there was no much variation in soil salinity at different depths. There was reduction in ECe in 0-90 cm depth, while it increased in 90-120 cm depth. This could be due to the fact that the salts got accumulated more at the surface layers in pre-drainage situation over a period of time due to development of water logging and salinity by excess flow of water along with salts and by the processes of high evaporative demands and capillary action. After the installation of SSDs, the paddy crop was taken up for cultivation.

Due to this, the surface layer salts were partly leached to deeper subsurface layers due to impounding of water by rainfall and irrigation and by infiltration and deep percolation processes and were partly discharged out by drainage water through the laterals and the collector drains. Manjunath (Majunath et al., 2004) noted that the average salinity in the top soil of the study area decreased from an initial value of $8.40 \pm 0.80$ to $2.60 \pm 0.40 \mathrm{dS} \mathrm{m}^{-1}$ during kharif 1998 and further to $2.10 \pm 0.50$ dS m-1 during rabi 1998-1999. The harmful salts that were brought in by the irrigation water were also reduced to a level ranging from 1.20 to $35.40 \mathrm{dS} \mathrm{m}^{-1}$ (Babu et al., 2008). The results of the present study were in agreement with similar findings (Patra et al., 2000; Kamble et al., 2006; Babu et al., 2010).

\section{Exchangeable calcium and magnesium}

The results of the exchangeable calcium and magnesium $\left(\mathrm{Ca}^{2+}+\mathrm{Mg}^{2+}\right)$ values of soil samples drawn at depths at 0-30, 30-60, 60-90 and $90-120 \mathrm{~cm}$ at various points before the transplantation and after the harvesting during kharif 2015-'16 are presented in Table 3. The mean exchangeable calcium and magnesium before transplantation during kharif 2015 at Gundur village were ranged from 33.49 to $36.92 \mathrm{meq}(100 \mathrm{~g})^{-1}$ for different depths. 
Table.1 Effect of SSD on soil reaction before transplantation and after harvesting at Gundur village (Head region of TLBC) during kharif 2015-'16

\section{kharif 2015-'16}

\begin{tabular}{|l|c|c|c|c|c|c|c|c|}
\hline \multicolumn{7}{|c|}{ Soil reaction $(\mathrm{pH})$} \\
\hline & \multicolumn{9}{c|}{ Before transplantation } & \multicolumn{4}{c|}{ After harvesting } \\
\hline Soil depth, cm & $\mathbf{0 - 3 0}$ & $\mathbf{3 0 - 6 0}$ & $\mathbf{6 0 - 9 0}$ & $\mathbf{9 0 - 1 2 0}$ & $\mathbf{0 - 3 0}$ & $\mathbf{3 0 - 6 0}$ & $\mathbf{6 0 - 9 0}$ & $\mathbf{9 0 - 1 2 0}$ \\
\hline Mean & 8.25 & 8.40 & 8.50 & 8.66 & 8.28 & 8.42 & 8.53 & 8.68 \\
\hline Standard error & 0.04 & 0.03 & 0.06 & 0.05 & 0.06 & 0.05 & 0.04 & 0.06 \\
\hline Minimum & 8.12 & 8.23 & 8.31 & 8.42 & 7.95 & 8.01 & 8.23 & 8.45 \\
\hline Maximum & 8.51 & 8.73 & 8.83 & 8.92 & 8.53 & 8.75 & 8.84 & 8.94 \\
\hline
\end{tabular}

Table.2 Effect of SSD on soil salinity before transplantation and after harvesting at Gundur village (Head region of TLBC) during kharif 2015-'16

\begin{tabular}{|l|c|c|c|c|c|c|c|c|}
\hline \multicolumn{7}{c|}{ Kharif 2015-'16 } \\
\hline \multicolumn{7}{|c|}{ Sefore transplantation } & \multicolumn{4}{c|}{ After harvesting } \\
\hline Soil depth, cm & $\mathbf{0 - 3 0}$ & $\mathbf{3 0 - 6 0}$ & $\mathbf{6 0 - 9 0}$ & $\mathbf{9 0 - 1 2 0}$ & $\mathbf{0 - 3 0}$ & $\mathbf{3 0 - 6 0}$ & $\mathbf{6 0 - 9 0}$ & $\mathbf{9 0 - 1 2 0}$ \\
\hline Mean & 13.19 & 11.87 & 9.94 & 9.03 & 12.84 & 10.36 & 8.68 & 8.15 \\
\hline Standard error & 0.12 & 0.16 & 0.17 & 0.18 & 0.15 & 0.17 & 0.16 & 0.17 \\
\hline Minimum & 10.67 & 9.36 & 7.45 & 8.22 & 10.88 & 8.76 & 7.25 & 7.01 \\
\hline Maximum & 15.78 & 14.33 & 13.27 & 12.68 & 13.65 & 12.87 & 10.82 & 9.98 \\
\hline
\end{tabular}

Table.3 Effect of SSD on Exchangeable calcium and magnesium before transplantation and after harvesting at Gundur village (Head region of TLBC) during kharif 2015-'16

\begin{tabular}{|c|c|c|c|c|c|c|c|c|}
\hline \multicolumn{9}{|c|}{ kharif 2015-'16 } \\
\hline \multicolumn{9}{|c|}{$\mathrm{Ca}^{2+}+\mathrm{Mg}^{2+}\left(\operatorname{meq}(100 \mathrm{~g})^{-1}\right)$} \\
\hline & \multicolumn{4}{|c|}{ Before transplantation } & \multicolumn{4}{|c|}{ After harvesting } \\
\hline Soil depth, cm & 0-30 & $30-60$ & $60-90$ & 90-120 & 0-30 & $30-60$ & $60-90$ & $90-120$ \\
\hline Mean & 36.92 & 34.62 & 33.33 & 33.49 & 35.86 & 33.58 & 32.19 & 32.86 \\
\hline Standard error & 0.53 & 0.72 & 0.78 & 0.76 & 0.61 & 0.75 & 0.92 & 0.84 \\
\hline Minimum & 32.50 & 29.70 & 22.40 & 23.10 & 31.70 & 29.10 & 28.30 & 28.40 \\
\hline Maximum & 39.20 & 37.70 & 34.10 & 33.80 & 38.60 & 36.40 & 35.70 & 32.30 \\
\hline
\end{tabular}


Table.4 Effect of SSD on Exchangeable sodium before transplantation and after harvesting at Gundur village (Head region of TLBC) during kharif 2015-'16

\begin{tabular}{|l|c|c|c|c|c|c|c|c|}
\hline \multicolumn{7}{c|}{ kharif $^{-2015-' 16}$} \\
\hline & \multicolumn{9}{c|}{ Na $^{+}\left(\right.$meq $\left.(100 \mathrm{~g})^{-1}\right)$} \\
\hline Soil depth, cm & $\mathbf{0 - 3 0}$ & $\mathbf{3 0 - 6 0}$ & $\mathbf{6 0 - 9 0}$ & $\mathbf{9 0 - 1 2 0}$ & $\mathbf{0 - 3 0}$ & $\mathbf{3 0 - 6 0}$ & $\mathbf{6 0 - 9 0}$ & $\mathbf{9 0 - 1 2 0}$ \\
\hline Mean & 11.58 & 10.13 & 9.65 & 9.29 & 10.43 & 9.34 & 9.03 & 8.81 \\
\hline Standard error & 0.09 & 0.13 & 0.17 & 0.18 & 0.07 & 0.12 & 0.17 & 0.19 \\
\hline Minimum & 9.61 & 8.54 & 8.12 & 7.96 & 9.45 & 8.33 & 8.07 & 7.25 \\
\hline Maximum & 12.24 & 11.87 & 10.48 & 10.11 & 11.69 & 10.57 & 10.38 & 9.46 \\
\hline
\end{tabular}

Table.5 Effect of SSD on Exchangeable sodium percentage before transplantation and after harvesting at Gundur village (Head region of TLBC) during kharif 2015-'16

\begin{tabular}{|l|c|c|c|c|c|c|c|c|}
\hline \multicolumn{7}{c|}{ kharif 2015-'16 } \\
\hline & \multicolumn{9}{c|}{ ESP } \\
\hline & \multicolumn{9}{c|}{ Before transplantation } & \multicolumn{4}{c|}{ After harvesting } \\
\hline Soil depth, cm & $\mathbf{0 - 3 0}$ & $\mathbf{3 0 - 6 0}$ & $\mathbf{6 0 - 9 0}$ & $\mathbf{9 0 - 1 2 0}$ & $\mathbf{0 - 3 0}$ & $\mathbf{3 0 - 6 0}$ & $\mathbf{6 0 - 9 0}$ & $\mathbf{9 0 - 1 2 0}$ \\
\hline Mean & 17.45 & 15.94 & 13.67 & 12.85 & 16.31 & 14.96 & 12.68 & 12.03 \\
\hline Standard error & 0.45 & 0.47 & 0.49 & 0.51 & 0.39 & 0.42 & 0.44 & 0.61 \\
\hline Minimum & 15.86 & 13.42 & 11.89 & 11.23 & 14.48 & 12.37 & 10.83 & 9.67 \\
\hline Maximum & 19.83 & 17.37 & 15.28 & 14.09 & 18.42 & 16.28 & 14.17 & 13.36 \\
\hline
\end{tabular}

Fig.1 Effect of SSD on soil salinity before transplantation and after harvesting at Gundur village

(Head region of TLBC) during kharif 2015-'16

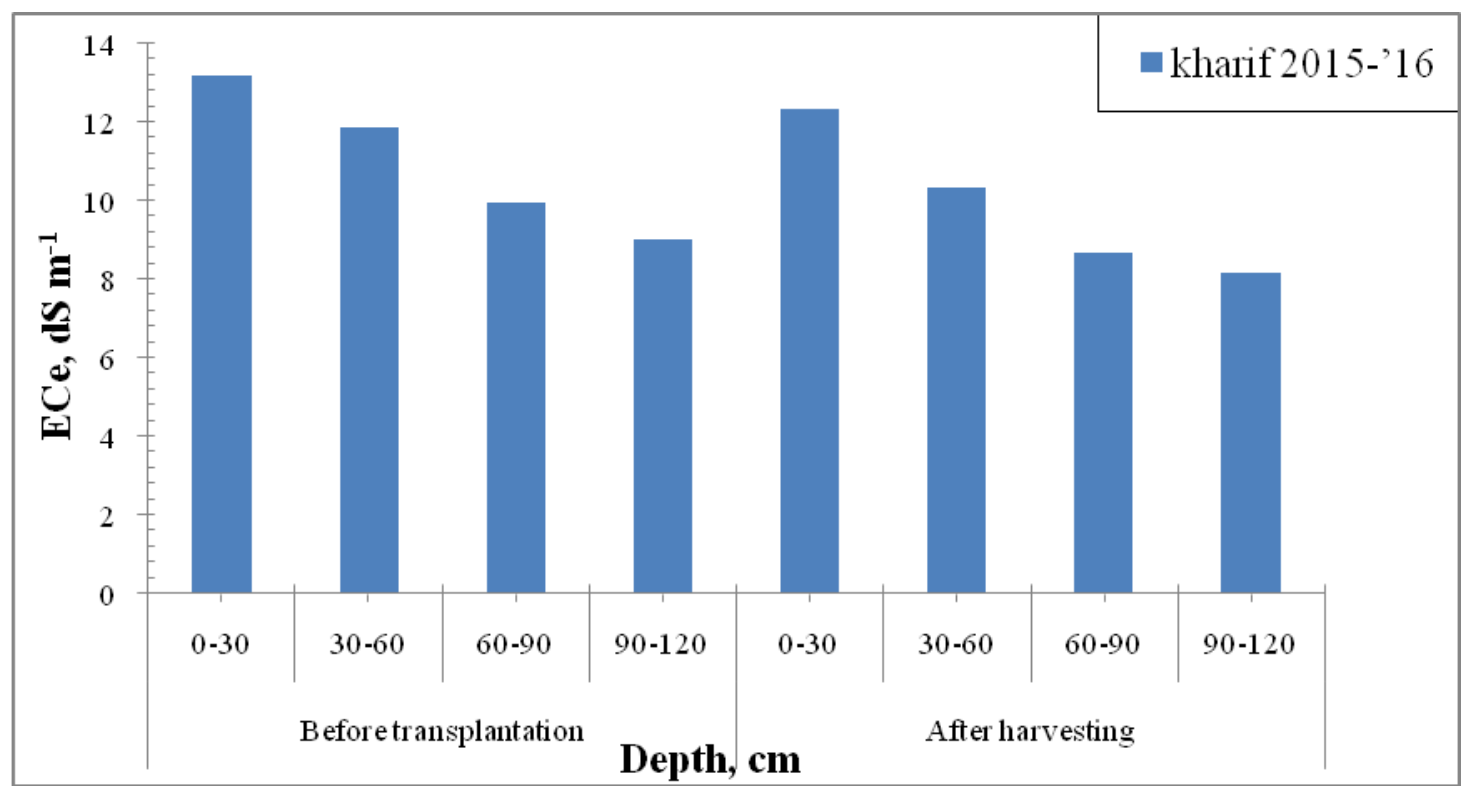


Fig.2 Effect of SSD on exchangeable sodium percentage before transplantation and after harvesting at Gundur village (Head region of TLBC) during kharif 2015-'16

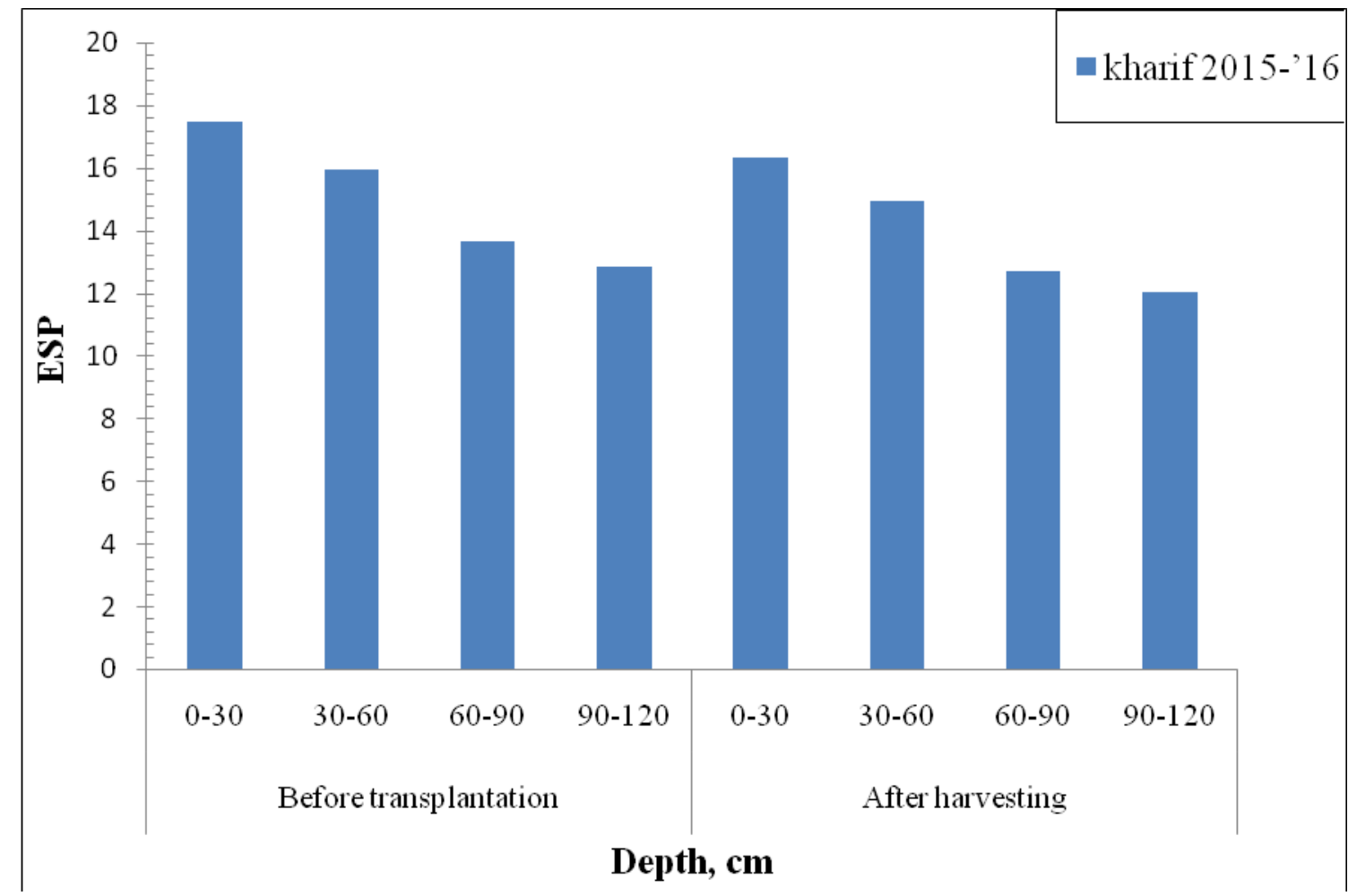

Fig.3 Effect of SSD on exchangeable sodium percentage before transplantation and after harvesting at Gundur village (Head region of TLBC) during kharif 2015-'16

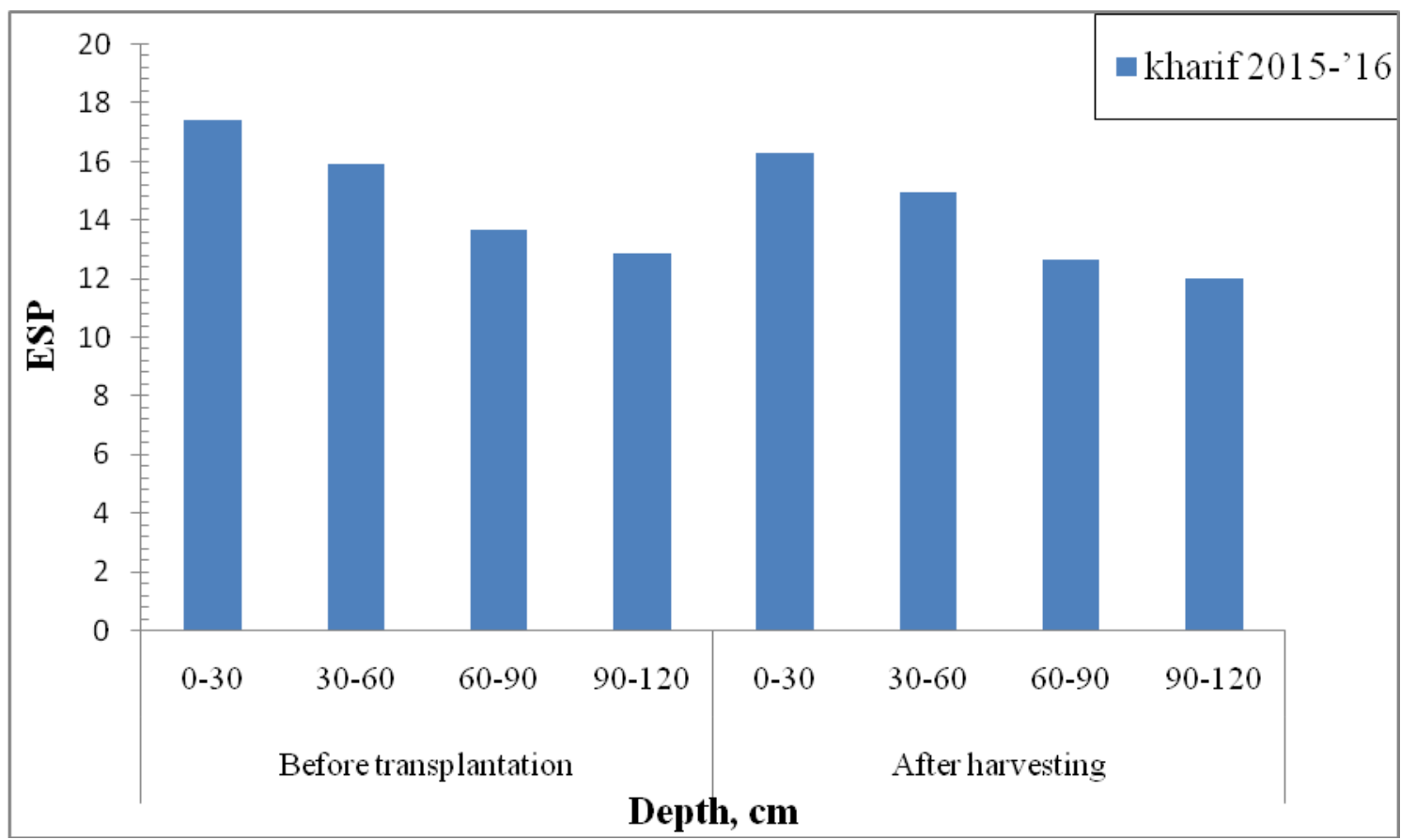


The standard error values for different depths of $0-30,30-60,60-90$ and $90-120 \mathrm{~cm}$ were found to be $0.53,0.72,0.78$ and 0.76 respectively, which indicated that there was little variation in exchangeable calcium and magnesium values drawn from same depths at different points. Similarly during the after harvesting of the paddy crop, the mean exchangeable calcium and magnesium values were 32.86 to $35.86 \mathrm{meq}(100 \mathrm{~g})^{-1}$. As compared to before transplantation data the mean salinity was decreased after harvesting. This was in line with the findings (Mathew et al., 2001).

\section{Exchangeable sodium}

The results of exchangeable sodium $\left(\mathrm{Na}^{+}\right)$ values of soil samples drawn at 0-30, 30-60, 60-90 and 90-120 cm depths at different points before transplantation and after the harvesting during kharif 2015 are presented in Table 4 and Figure 2. The Table 4 reveals that the mean, minimum, maximum and standard error values for exchangeable sodium before kharif transplantation 2015. The mean values of exchangeable sodium ranged from 9.29 to $11.58 \mathrm{meq}(100 \mathrm{~g})^{-1}$, while the highest and lowest values were observed at $0-30 \mathrm{~cm}$ and 90-120 cm depths respectively. The standard error values for $0-30,30-60,60-90$ and 90 $120 \mathrm{~cm}$ depths were $0.09,0.13,0.17$ and 0.18 meq $(100 \mathrm{~g})^{-1}$ respectively, which indicated that there were no much variations in the $\mathrm{Na}^{+}$ values at different points of soil samples drawn at same depths. The exchangeable sodium content of soil observed after the harvesting of the kharif 2015 crop or before transplantation of rabi 2016 crop revealed that the mean $\mathrm{Na}^{+}$ranged from 8.81 to 10.43 meq $100 \mathrm{~g}^{-1}$. The magnitudes of standard error were $0.07,0.12,0.17$ and 0.19 meq (100 $\mathrm{g})^{-1}$ respectively for different depths of 0-30, 30-60, 60-90 and 90-120 cm, which indicated that there were no much differences in the $\mathrm{Na}^{+}$values of soil samples drawn at particular depths and different points. The soil exhibited higher exchangeable sodium content in the surface layer than that of the deeper layers due to higher evaporation and capillary rise of dissolved sodium in the summer season. With the ponding of water after the transplanting of the paddy crop, part of the sodium was dissolved in the water and drained away. Though the drains were found working well, but not found much efficient in the reduction of the sodium concentration.

\section{Exchangeable sodium percentage}

The mean exchangeable sodium percentage (ESP) values of the soil samples before transplantation and after harvesting during kharif 2015 drawn from different depths of 0 $30,30-60,60-90$ and $90-120 \mathrm{~cm}$ are presented in Table 5 and Figure 3. The Table 5 scrutinize that minimum, maximum, mean and standard error values of ESP of the soil samples of before transplantation kharif 2015 at Gundur village. The mean lowest and highest ESP have been found to be 11.23 at $90-120 \mathrm{~cm}$ and 19.83 at 0 to $30 \mathrm{~cm}$ depths respectively, with their mean value varied from 12.85 to 17.45 . The standard error values at different depths of 0-30, 30-60, 6090 and $90-120 \mathrm{~cm}$ are $0.45,0.47,0.49$ and 0.51 respectively, which revealed that there were no much variations in ESP of soil samples drawn from particular depths and different points. Similarly, the minimum, maximum, mean and standard error values of ESP for the soil samples after the harvest during kharif 2016 are shown in Table 5. The minimum value of ESP has been found to be 9.67 at $90-120 \mathrm{~cm}$ depth against the maximum ESP value of 18.42 at $0-30 \mathrm{~cm}$ depth, with their mean value ranged from 12.03 to 16.31 , while the magnitudes of standard errors observed were $0.39,0.42,0.44$ and 0.61 for $0-30,30-60,60-90$ and $90-120$ $\mathrm{cm}$ depth respectively, which showed that there was no much difference in ESP of soil 
samples drawn from particular depths and also at different points. This meant that there was significant difference in the mean exchangeable sodium percentage values of the soil samples drawn before sowing and after harvesting. The reduction in ESP was due to the SSD system, which helped in leaching of salts. However, the reduction was not considerable without the application of gypsum as it was to needed to be applied from the soil (Jadhao et al., 2009). With application of the gypsum in the following season(s), it is expected that the reclamation process would be complete by significant reduction in ESP. These results were in agreement with that of the studies, which revealed that the ESP reduced after the implementation of the subsurface drainage system (Kamble et al., 2006; Pradeep et al., 2005).

\section{Land Improvement and Crop Performance Studies}

It was observed that out of 149.25 ha land, earlier only 35.34 ha was utilized for the purpose of cultivation due to perpetual water logging and salinity problems caused by unscientific practices of land and water after the advent of irrigation. However, as a result of the drainage work, the land conditions improved. After the installation of the SSD system, the cropped area increased from 35.34 to 118.86 ha. The post-drainage yield also increased to $52.50 \mathrm{q} \mathrm{ha}^{-1}$ as compared to pre-drainage yield of $38.50 \mathrm{q} \mathrm{ha}^{-1}$, which meant an increase of 36.36 per cent. Increase in grain yield due to subsurface drainage was reported in previous studies (Barker, 2000; Mathew et al., 2001; Girish, 2003; Satyanarayana and Boonstra, 2007; Ritzema et al., 2008).

Based on the observation and analysis of the soils samples collected before sowing and after harvesting it could be observed that the $\mathrm{ECe}, \mathrm{Ca}^{2+}+\mathrm{Mg}^{2+}$ and $\mathrm{Na}^{+}$content was found to be reduced significantly as compared to pre-sowing conditions but the soil reaction was found to be increased due to increase in saline-sodicity of the soil and higher application of fertilizers. finally ESP was observed to be reduced in smaller amount as compared to pre sowing conditions, there is need of application of gypsum in requires amount in order to turn in to non-saline soils. The crop yield was observed to be increased by 36.36 per cent as compare to pre drainage conditions.

\section{References}

Babu G., Kishore, Chandra S., Ramesh, Reddy K.Y., Rao G., Subba and Radha Y. (2008) A.P. Water Management Project, Bapatla, pp: 21-27.

Babu P.B., Babu M.R., Prasad P. R. K., Lakshmi G.V. and Gupta S. K.(2010) AICRP on manage. Salt affected soils and use of saline water in Agriculture. Bapatla, Andhra Pradesh, India.

Barker R.D. (2000) M. Tech. Thesis submitted to Uni. Agric. Sci., Dharwad.

Fard B.M., Heidarpour M.A., Abbas, Feizi M. (2007). Intl. J. Agric. Biol., 9(3), 74-78.

Girish B.D. (2003) Unpublished M. Tech. Thesis submitted to Univ. Agric. Sci., Dharwad

Jadhao S.M., Konde N.M., Patil A.S., Nillam M.K.(2009) Impact assessment of subsurface drainage with saline-sodic swell shrink soils. Indian J. Agric. Res., 43(2), 113- 118.

Kamble B.M., Chougule B.A., Rathod S.D. and Rathod P.K. (2006) Improvement of salt affected - water logged soils in western maharashtra through subsurface drainage (Ssd) system. Asian J. Bio Sci., 1(2), 64-67.

Majunath M.V., Oosterboan R.J., Gupta S.K., Rajkumar H. and Jansen H. (2004) Performance of subsurface drains for reclaiming waterlogged saline lands 
under rolling topography in Tungabhadra irrigation project in India. Agric. Water Manage., 69(1), 69-82.

Mathew E.K., Panda R.K. and Madhusuda N. (2001) Influence of subsurface drainage on crop production and soil quality in a low-lying acid sulphate soil Agric. Water Manage., 47(1), 191-209.

Patra S.K., Ray R., Senapati T.K. and Mukhopadhyay A.K. (2000) J. Agric. Engg., 37(2), 39-44.

Pradeep H.M., Hebsur N.S., Gali S.K., Koti R.V. (2005) Effect of Sub-Surface Drainage and Amendments on Soil Physical and Chemical Properties of
Black Soil of Ghataprabha Command Area. J. Agric. Sci., 18(3), 953-958.

Ritzema H.P., Satyanarayana T.V., Raman S. and Boonstra J. (2008) Subsurface drainage to combat waterlogging and salinity in irrigated lands in India: Lessons learned in farmers' fields. Agric. Water Manage., 95(1), 179-189.

Satyanarayana T.V. and Boonstra J. (2007) Irrig. Drain., 56: 245-252.

Srinivasulu A., Satyanarayana T.V., Babu R.M. and Kumar H.V. (2006) J. Agric. Engg., 43(1), 8-12.

\section{How to cite this article:}

Mallika, K., M.S. Ayyanagowdar, B.S. Polisgowdar, U. Satish Kumar, M.V. Ravi and Nagaraj. 2018. Effect of Sub-Surface Drainage System on Soil Chemical Properties and Yield of Rice Crop at Head Region of Tungabhadra Command Area. Int.J.Curr.Microbiol.App.Sci. 7(10): 1212-1220. doi: https://doi.org/10.20546/ijcmas.2018.710.135 